\title{
The Implementation of School Based Management, and Its Effect on the Teachers' Work Motivation and the School Quality
}

\author{
Ibrahim Bafadal, Bambang Budi Wiyono*, Ahmad Yusuf Sobri \\ Department of Educational Administration, Faculty of Education, State University of Malang, Indonesia
}

Copyright $(2019$ by authors, all rights reserved. Authors agree that this article remains permanently open access under the terms of the Creative Commons Attribution License 4.0 International License

\begin{abstract}
The three main purposes of the study were: (1) to describe the implementation of the school-based management, (2) to know the effect of the implementation of the school-based management on the teachers' work motivation, and (3) to know the effect of the school-based management on the school quality. The study was conducted in East Java, and the samples of the study were 87 , which were taken by using area cluster random sampling technique. The data was collected by using questionnaire and then was analyzed by using descriptive statistic, regression, and qualitative data analysis. Based on the analysis results, it could be concluded that the implementation of school-based management in East Java was mostly categorized as good enough. Some components which were categorized as good were the formulation of the school visions, the development of the school programs, the school transparency, the empowerment of the school resources, and the society involvement. Some components which were still categorized as poor were the school independence and the school renewal. There was significant effect of the implementation of the school-based management on the teachers' work motivation and the school quality.
\end{abstract}

Keywords School-based Management, Work Motivation, School Effectiveness

\section{Introduction}

The school-based management (SBM) was one of the strategic policies of the national education, which was in line with the Law number 20 of the year 2003. In the said law, it was emphasized that SBM was a management approach, which should have to be implemented at elementary schools as the part of the elementary education unit and based on the minimum service standards. The implementation of the SBM motivated the schools to become more active, independent, open, and accountable in carrying out the programs to improve the education quality according to the school needs which was accompanied by the participative decision making.

There are some elements showing the characteristics of school based management, namely independence, inovation, transparency, school resources empowerment, and community involvement. In addition, vision, missions, goals, and programs of school are formulated and conducted well. The main objective is to improve the quality of education in school optimally.

When it was reviewed further, the implementation of the school-based management had positive values in carrying out the education at schools, but it also demanded bigger responsibility to the schools. Those conditions would lead to the implementation of the school-based management. Schools which had the sufficient resources tended to have bigger chances to implement the school-based management well while the schools which had poor resources tended to have higher chances to implement the school-based management optimally. However, it was still a question. In order to obtain stronger empiric data, a study should be conducted.

The school-based management had been implemented at schools of various levels. There were some schools implementing the school-based management well, medium, or poor. Related to the aforementioned statement, in order to achieve the targets of the strategic plans of the Ministry of Education and Culture in 2014, 90\% of schools, especially elementary schools, implemented the school-based management well, and continuous strategic plans were needed. To achieve the targets of the strategic plans which were suitable with the main duties and functions, the Directorate of Primary School Development conducted technical supervision of the school-based management as one of the parts of primary school development wholly (Directorate of Primary School Development, 2013).

The results of the study conducted by Wiyono (2001) 
indicated that the readiness of the education holders such as the teacher and the principals in implementing the school management system which was the school-based management was good, but some aspects still needed supervising. On the other hand, based on the literature or the exploration study through internet, the research related to the school-based management at schools, especially the one concerning about the effect of the implementation of school-based management was still rarely conducted. One of the researches conducted by Wiyono (2017) showed that there was effect of school-based management implementation on education quality in school. How the effect of the school-based management implementation on personnels in school is still not widely known. Meanwhile, the information related to the implementation of the school-based management was essential as the basis to formulate the policies to improve the school-based school quality. Based on the aforementioned background, the current study was conducted.

The present study was intended to describe the implementation of school-based management at schools, especially in East Java. Through the current study, it was expected to find how the school-based management was implemented at schools, what factors supported and prevented the implementation of the school-based management, and how the effect of the implementation of the school-based management on the improvement of the education quality at schools. The three main formulated purposes were: (1) to describe the implementation of the school-based management in East Java, (2) to find the degree of the effect of the implementation of the school-based management on the teachers' work motivation, and (3) to find the effect of the school-based management implementation on the quality or the effectiveness of the schools. Based on the given information, it was expected to become the basis to develop theories and make policies in order to improve the education quality at schools through the improvement and the perfection of the school-based management implementation in the future.

\section{Experimental Details}

The present study was aimed to describe the implementation of the school-based management at schools in East Java, the supporting factors, the preventing factors, the level of success, and the effect of the implementation of the school-based management on the teachers' work motivation and the school effectiveness. The research design used was descriptive correlational study. In order to obtain further data, qualitative method (mixing method) was added. The quantitative data was analysed by using quantitative data analysis, and the qualitative one was analysed by using qualitative data analysis. (Johnson \& Christensen, 2004)

The population of the current study was the schools in East Java and the samples, which were 87 , were taken by using area cluster random sampling. In order to obtain the data, two techniques which were questionnaire and documentation were used. The questionnaire was used to collect the data related to the implementation of the school-based management at schools, the practices including the supporting and the preventing factors, the degree of success, the teachers' work motivation, and the school effectiveness. The documentation technique was used to complete the data obtained through the questionnaire, especially the one related to the documentative data such as the document related to the school characteristics and the school resource.

The research instrument was developed based on the research variable. The questionnaire includes both open and close one. Before the instrument was used, try out was carried out in order to the reliability and the validity of the instrument. The results of the try out suggested that the instrument was valid and reliable with $r>0.7$.

According to the research purpose and considering the existing data, three data analysis techniques were implemented: descriptive statistic, correlation, and qualitative data analysis techniques. The descriptive statistic was used to describe the research results which were the implementation and the supporting as well the preventing factors, and the success of the school-based management implementation at schools in East Java. The correlation analysis technique was used to test the correlation or the effect of the implementation of the school-based management on the teachers' work motivation and the school effectiveness. The qualitative data analysis was used to obtain the in-depth information related to the implementation of the school-based management. The data analysis was conducted by analysing all the available data, reducing the data, categorizing, and giving meaning to the results. The data analysis was done step by step and the ongoing improvement was applied since the beginning of the field research until the end of the research. The conclusion drawing was done by finding the meaning, the patterns, the explanation, the cause and effect plot, and the proposition making.

\section{Results and Discussion}

The implementation of the school-based management at schools in East Java could be seen from the school visions and missions, the transparency, the independence, the school renewal, the accountability, the empowerment of the school resource, and the society involvement. In formulating the school visions and missions, schools involved the principals, the teachers, the administrative staffs, the school committee, the students, the parents, and the school superintendents. In realizing the visions and the missions, schools created the strategic purposes and determined the short-term target. Based on the indicators, the analysis results showed that $1.1 \%$ was very poor, $36 \%$ was poor, $56 \%$ was good enough, and $7 \%$ was very good. 
In formulating the school programs, the principals, the teachers, the administrative staffs, and the school committee. The school programs were also informed to the teachers, the administrative staffs, the school committee, the students, the parents, and the superintendents. The school programs were informed through coordination meeting, notice board and written letters. In terms of the school programs making, the analysis results suggested that $3.4 \%$ was very poor, $5.7 \%$ was poor, $46 \%$ was good enough, and $44.8 \%$ was very good.

The teaching and learning programs at school was managed by the schools themselves starting from the making, the planning, the determination of the teaching and learning strategy or method, the use of teaching and learning sources, and the evaluation of the teaching and learning program. The monetary issue was also fully managed by the schools starting from the budget planning, the receival, the use, and the accountability. The facilities and the infrastructure was also fully managed by the schools starting from the provision, the use, the maintenance, and the deletion of items. In terms of the independence in formulating the school programs, the analysis results suggested that $5 \%$ was very poor, 64.4 was poor, and $31 \%$ was good enough. In order to improve the education quality, schools renewed and the result analysis showed that $5 \%$ was very poor, $64.4 \%$ was poor, and $31 \%$ was good enough.

In making the activity plan and the school budget, the schools involved the principals, the teachers, the administrative staffs, the school committee, parents, and school superintendents. The source of the school budget was the government, parents, and society. The principals delegated the budget management to the school members. Every income and expenditure was noted. Schools wrote the accountability report of the school income and expenditure monthly, once in every three months, and annually. The accountability report was given to the Education Department, the school committee, and the parents both in the written and spoken forms trough the school notice board. In terms of the school accountability, the results analysis showed that $1.1 \%$ was very poor, 48.3 was poor, $48.4 \%$ was good enough, and $1.1 \%$ was very good.

The school programs were delegated to all the school members depending on their capacity and ability. In carrying out the school duties, the principals created the job description for each school member. They also organized the member development through workshop, seminar, teamwork meeting, discussion, class visit, or meeting. Schools provided prosperity, help, support, or chances to the members to develop themselves. In term of the empowerment of the school resources, the results of the analysis suggested that $26.4 \%$ was poor, $72.4 \%$ was good enough, and $1.1 \%$ was very good.

In order to improve the society participation, schools did some promotion to the society. To support the education process, the schools had good communication and cooperation with all interested parties. The communication techniques used to cooperate with the society were meeting, written report, home visit, exhibition, bazar, and so on. The society participation in organizing the education was in the form of providing fund, facilities, and expertise. In terms of the society involvement, the results of the analysis suggested that $12 \%$ was very poor, $54 \%$ was poor, $28 \%$ pas good enough, and $6 \%$ was very good. All in all, in terms of the implementation of the school-based management, the results of the analysis showed that $27 \%$ was poor, $71 \%$ was god enough, and $2 \%$ was very good.

The teachers' work motivation had several indicators, such as the teachers were enthusiastic in carrying out their duties to do the teaching and learning process daily, to evaluate the teaching and learning continuously, to provide remedial and enrichment tasks for the students to come to the schools on time, to pursue higher education, to join any seminars, discussion, or any other scientific activities, and to do the administrative duties as well as others. In terms of the teachers' work motivation, the results of the analysis suggested that $1.1 \%$ was poor, $11.5 \%$ was good, and $87.4 \%$ was very good.

The school quality has a lot of factors. One of the main indicators, which could be used as reference was school accreditation. In terms of the school quality, the accreditation was $41.4 \% \mathrm{~A}, 53.3 \% \mathrm{~B}$, and $2.3 \% \mathrm{C}$.

There were some problems in implementing the school-based management. The problems were: (1) the limited fund, (2) the lack of the society participation, (3) the presence of parents who did not understand and unite well, (4) the lack of the parents' awareness, (5) the lack of facilities and infrastructure, (6) the uneven skills of the teachers, (7) the lack of cooperation and communication, (8) the stakeholders who were not very supportive, and (9) the low economy levels of the parents.

Some problems were solved by the schools such as (1) improving the cooperation and the communication with the society, (2) adding the power, (3) improving the human resources, (4) completing the facilities and infrastructure, (5) improving the teachers' discipline, (6) improving the society awareness, and (7) improving the supporting facilities.

Based on the results of the hypothesis test, in general, it could be said that the coefficient of the correlation between the implementation of the school-based management and the school effectiveness was 0.381 and $p<0.05$ which was represented by the scores of the school accreditation. Therefore, it could be concluded that there was a significant correlation between the implementation of school-based management and school effectiveness. The higher the implementation of the school-based management was, the better school effectiveness was. Partially the relationship between the elements of school-based management with teacher morale and school quality is presented in Table 1. 
Table 1. Correlation between Elements of School-Based Management with Teacher's Work Motivation and School Quality

\begin{tabular}{|c|c|c|}
\hline Elements of SBM & $\begin{array}{c}\text { Teacher's Work } \\
\text { Motivation }\end{array}$ & School Quality \\
\hline Formulation of the school visions & $\mathrm{r}=0.168$ & $\mathrm{r}=0.262^{*}$ \\
\hline Formulation of the school programs & $\mathrm{r}=0.198$ & $\mathrm{r}=0.084$ \\
\hline School independence & $\mathrm{r}=-0.149$ & $\mathrm{r}=0.207$ \\
\hline School renewal & $\mathrm{r}=0.180$ & $\mathrm{r}=0.180$ \\
\hline School transparency & $\mathrm{r}=0.138$ & $\mathrm{r}=0.171$ \\
\hline Empowerment of the school resources, & $\mathrm{r}=0.108$ & $\mathrm{r}=0.368^{*}$ \\
\hline
\end{tabular}

$* \mathrm{p}<0.05$

Based on the Table 1, it is concluded that the coefficient of the correlation between the formulation of the school visions and the teachers' work motivation which was represented the scores of the teachers' work motivation was 0.168 and $p>0.05$. Therefore, it could be concluded that there was not a significant correlation between the formulation of the school visions and the teachers' work motivation. The higher score of the formulation of the school visions was not followed by the improvement of the teachers' work motivation. Meanwhile, the coefficient of correlation between the formulation of the school visions and the school effectiveness which was represented by the school accreditation was 0.262 and $p<0.05$. Therefore, it could be concluded that there was a significant correlation between the formulation of the school visions and the school effectiveness which was represented by the school accreditation. The better the formulation of the school visions was, the better the school effectiveness was.

The coefficient of the correlation between the formulation of the school programs and the teachers' work motivation which was represented by the scores of the teachers' work motivation was 0.198 and $\mathrm{p}>0.05$. Therefore, it could be concluded that there was not a significant correlation between the making of the school programs and the teachers' work motivation. The better making of the school programs was not followed by the improvement of the teachers' work motivation. In contrast, the coefficient of the correlation between the making of the school programs and the school effectiveness, which was represented by the scores of the accreditation was 0.316 and $p<0.05$. Therefore, it could be said that there was a significant correlation between the making of the school programs and the school effectiveness. The better the making of the school programs was, the better the school effectiveness was.

In terms of the school independence, the coefficient of the correlation between the school independence and the teachers' work motivation which was represented by the scores of the teachers' work motivation was -0.149 and $p>$ 0.05 . It meant that there was no significant correlation between the school independence and the teachers' work motivation. Although the school independence was better, it was not followed the improvement of the teacher's work motivation. On the other hand, the coefficient of the correlation between the school independence and the school effectiveness, which was represented by the scores of the accreditation was 0.084 and $p>0.05$. Therefore, it could be concluded that there was not significant correlation between the school independence and the school effectiveness. It meant that the improvement of the school independence was not accompanied by the improvement of the school effectiveness.

In terms of the school renewal component, it could be said that the coefficient of the correlation between the school renewal and the teachers' work motivation which was represented by the scores of the teachers' work motivation was 0.180 and $p>0.05$. Thus, it could be concluded that there was no significant correlation between the school renewal and the teachers' work motivation. It meant that the renewal of the school was not followed by the improvement of the teachers' work motivation. Meanwhile, the coefficient of correlation between the school renewal and the school effectiveness which was represented by the scores of accreditation was 0.207 and $p>$ 0.05 . Therefore, it could be said that there was no significant correlation between the school renewal and the school effectiveness.

In terms of the school transparency, the coefficient of the correlation between the school transparency and the teachers' work motivation which was represented by the scores of the teachers' work motivation was 0.138 and $p>$ 0.05 . Thus, it could be said that there was no significant correlation between the school transparency and the teachers' work motivation. The improving school transparency was not accompanied by the improvement of the teachers' work motivation. Meanwhile, the coefficient of the correlation between the school transparency and the school effectiveness which was represented by the scores of the accreditation was 0.180 and $p>0.05$. Therefore, it could be concluded that there was not significant correlation between the school transparency and the school effectiveness.

In terms of the empowerment of the school resources, the coefficient of the correlation between the school resources and the teachers' work motivation which was represented by the scores of the teachers' work motivation 
was 0.108 and $p>0.05$. Thus, it could be said that there was no significant correlation between the school resources and the teachers' work motivation. The improving empowerment of the school resources was not accompanied by the improvement of the teachers' work motivation. Meanwhile, the coefficient of the correlation between the empowerment the school resources and the school effectiveness which was represented by the status of the accreditation was 0.171 and $p>0.05$. Therefore, it could be concluded that there was not a significant correlation between the empowerment of the school resources and the school effectiveness.

In terms of the society involvement, the coefficient of the correlation between the society involvement and the teachers' work motivation which was represented by the scores of the teachers' work motivation was 0.203 and $p>$ 0.05 . Thus, it could be said that there was no significant correlation between the society involvement and the teachers' work motivation. Improving the society involvement was not accompanied by the improvement of the teachers' work motivation. Meanwhile, the coefficient of the correlation between the society involvement and the school effectiveness which was represented by the scores of the accreditation was 0.368 and $p<0.05$. Therefore, it could be concluded that there was significant correlation between the society involvement and the school effectiveness. The more the society involved, the better the school effectiveness was.

Based on the results of the hypothesis test, all in all, it could be said that the coefficient of the correlation between the school-based management and the teachers' work motivation which was represented by the scores of the teachers' work motivation was 0.230 and $p<0.05$. Thus, it could be said that there was significant correlation between the school-based management and the teachers' work motivation. The better the school-based management was, the higher the teachers' work motivation was.

The current research results supported the results of the study conducted by Wiyono (2008) which mentioned that there was some effect of the implementation of the school-based management on the quality of education at schools. They also agreed with the study conducted by Adam (2002) which stated that the implementation of the school-based management could improve the teachers' commitment in carrying out their duties.

The results of the study conducted by Elmelegy (2015) also suggested that the implementation of the school-based management could improve the quality of the decision-making through the empowerment of the teachers, the delegation of the authority, and the encouragement to make decision. The results of this study are also in line with the research results of Wiyono, Rasyad, and Ibrahim (2017) which showed that culture influence on work motivation and team work effectiveness of teachers. One of the characteristics of the school based management is to build employee work culture. As the work culture increase, work motivation and work effectiveness of the personnels also increase. The findings of the research was also supoorted to the study results of Santibañez et al. (2014) which showed that there was positive effects of the school-based management program on the third grade Spanish test scores.In addition the research result was in line with the study of Camminatiello et al (2012) which indicated that the school-based management has significant positive effect on the student achievement.

\section{Conclusions}

Based on the results of the data analysis, it could be said that there were some conclusions. First, there was a significant correlation between the implementation of the school-based management and the school effectiveness. The better the implementation of the school-based management was, the better the school effectiveness was. There were some components contributing significantly to the school effectiveness, which were the formulation of the school visions and missions, the making of the school programs, and the involvement of the society within the education process.

Second, based on the analysis results, it could be said that there was a significant correlation between the implementation of the school-based management and the teachers' work motivation. The better the implementation of the school-based management was, the better the teachers' work motivation was.

Based on the results of the current study, it is suggested that the school principals should implement the school-based management optimally in order to improve the school effectiveness. The main components which need concerning is the formulation and the achievement of the school visions and missions, the making and the implementation of the effective school programs, the school renewal, and the society involvement in improving the school quality.

Further, there was no positive and significant correlation between the teachers' work motivation and the school effectiveness. Therefore, it is important to find further and more comprehensive explanation for it. It is suspected that there is indirect correlation between the teachers' work motivation and the school effectiveness.

\section{REFERENCES}

[1] Adam, E.N. 2002. School Based Management and its Effect on Teacher Commitment. International Journal of Leadership in Education, Theory and Practice, 5 (2): 323-34.

[2] Camminatiello, I., Palleta, A., Speziale, M.T. 2012. The effects of school based management and standard based 
accountabilility on the students achievement: Evidence from PISA 2006. Electronic Journal of Applied Statistical Analysis, 5 (3), 381-386.

[3] Depdiknas. 2003. Manajemen Berbasis Sekolah untuk Sekolah Dasar (School Based Management in Elementary School). Jakarta: Depdiknas-Ditjen Dikdasmen.

[4] Depdiknas. 2003. Manajemen Peningkatan Mutu Berbasis Sekolah (School Based Quality Improvement in School). Jakarta: Depdiknas-Ditjen Dikdasmen.

[5] Elmelegy, R.T. 2015. School Based Management: An Approach to Decision Making Quality in Egyptian General Secondary Schools. School Leadership \& Management: Formenly School Organization, 35 (1): 79-96.

[6] Santibariez, L., Lastra, R.A., Donoghue, J.L.O. 2014. School based management effects: Resources or governance change? Evidence from Mexico. Economics of Education Review, 39, 97-109.

[7] Wiyono, B. B. 2017. The Effect of School Based Management Implementation on the Education Quality. Advanced Science Letters, 23 (9): 8612-8616

[8] Wiyono, B.B. 2008. Kemampuan Kepala Sekolah dalam Mengelola Sekolah dengan Pendekatan School Based Management (The Ability of Principals in School Management with the School Based Management Approach). Wahana Sekolah Dasar, 16 (2): 133-143.

[9] Wiyono, B.B., Rasyad, A., and Bafadal, I. 2017. The Influence of Organizational Culture to Work Motivation, Teamwork Effectiveness, and School Improvement, Man in India, 97 (18): 97-106. 